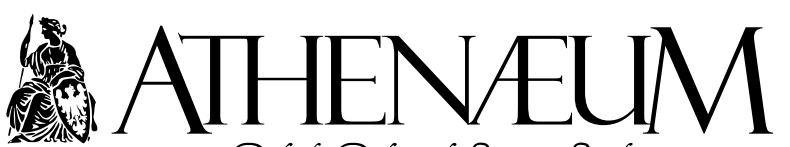

Polish Political Science Studies

Polskie Studia Politologiczne

vol. 72(4)/2021, pp. 168-187

DOI: 10.15804/athena.2021.72.10

www.athenaeum.umk.pl

ISSN 1505-2192

\title{
FRIENDS AND NEIGHBOURS VOTING IN LOCAL ELECTIONS IN OPEN LIST SYSTEM: EVIDENCE FROM POLAND
}

\author{
GŁOSOWANIE PRZYJACIELSKO-SĄSIEDZKIE W WYBORACH \\ LOKALNYCH W SYSTEMIE LIST OTWARTYCH: DANE Z POLSKI
}

Tomasz Czapiewski* @ , Monika Woźniak** •

This paper seeks to extend previous analyses of localism of candidates. To our knowledge, this is the first study of the 'friends and neighbours' voting (FNV) effect in Central and Eastern Europe employing the data of the candidate's exact place of residence and using dispersion of votes between electoral precincts, as in Poland votes in each precinct are counted and published separately. The basic hypothesis of the paper was that the place of residence is a factor that significantly affects the spatial distribution of votes. Using spatial autocorrelation, we identify spatial clusters of votes for specific candidates. The conducted research indicates that the intensity of the FNV effect differs between candidates. This local bonus, which in fact is the FNV effect, is an attribute of selected candidates. It can be seen that a candidate's locality is a more important attribute influencing voting results in certain city districts,
\end{abstract}

Niniejszy artykuł ma na celu poszerzenie dotychczasowych badań dotyczących lokalizmu kandydatów. Według naszej wiedzy jest to pierwsze w Europie Środkowo-Wschodniej badanie efektu głosowania przyjacielsko-sąsiedzkiego (FNV) z wykorzystaniem danych o dokładnym miejscu zamieszkania kandydata oraz zróżnicowaniu liczby głosów pomiędzy obwodami wyborczymi, gdyż w Polsce głosy w każdym obwodzie są liczone i publikowane osobno. Podstawową hipotezą pracy jest stwierdzenie, że miejsce zamieszkania to czynnik istotnie wpływający na przestrzenny rozkład głosów. Wykorzystując autokorelację przestrzenną, identyfikowane są przestrzenne skupiska głosów oddanych na konkretnych kandydatów. Przeprowadzone badania wskazują, że natężenie efektu FNV jest różne dla poszczególnych kandydatów. Ta lokalna premia, jaką jest efekt FNV, jest atrybutem wybranych

* University of Szczecin, Institute of Political Science and Security Studies.

** University of Szczecin, Institute of Economics and Finance. 
while in others it is of limited importance. This mechanism may be explained to some extent by referring to the notion of motivation to win personal votes and party strategies of the selectors. Moreover, it was proved that the spatial distribution of votes of candidates who have their place of residence in the area from which they stand for election is significantly different from the distribution of votes among non-resident candidates.

Keywords: local elections; friends and neighbours voting (FNV); personal votes; Szczecin kandydatów. Można zauważyć, że lokalność kandydata jest ważnym elementem wpływającym na wyniki głosowania w niektórych okręgach miejskich, a w innych ma ograniczone znaczenie. Mechanizm ten można do pewnego stopnia wyjaśnić, odwołując się do pojęcia motywacji do zdobywania głosów personalnych oraz strategii partyjnych selekcjonerów. Ponadto wykazano, że rozkład przestrzenny głosów kandydatów, którzy mają miejsce zamieszkania na obszarze, $\mathrm{z}$ którego kandydują, różni się istotnie od rozkładu głosów kandydatów niezamieszkałych w okręgu.

Słowa kluczowe: wybory samorządowe; głosowanie przyjacielsko-sąsiedzkie; głosy personalne; Szczecin

\section{INTRODUCTION}

Extensive literature has shown that in elections it matters where a candidate lives. The effect of the friends and neighbours voting (FNV) is a phenomenon widely described in political science literature, e.g., in countries such as: the United States (Key, 1949; Black \& Black, 1973; Johnston, 1974; Lewis-Beck \& Rice, 1983; Rice \& Macht, 1987a), the United Kingdom (Arzheimer \& Evans, 2012, 2014; Johnston et al., 2016), Canada (Blais et al., 2003; Roy \& Alcantara, 2015), New Zealand (Forrest \& Johnston, 1973), Austria (Eder, Jenny, \& Müller, 2015), the Netherlands (Hessels, 2013), Belgium (Put, 2015; André \& Depauw, 2018; Vandeleene, 2017), Germany (Jankowski, 2016), Norway (Fiva \& Smith, 2017), Finland (Arter, 2011), Estonia (Tavits, 2010), the Czech Republic (Malcová, 2012), Israel (Hazan, 1999), or Kenya (Simiyu, 2010). The simplest definition of the effect is that candidates receive more votes in their local area (most often their place of residence) than in more remote areas. As far as elections in Poland are concerned, the issue has not been widely discussed, either at the level of empirical research or more theoretically in review-oriented publications. The FNV effect was studied by Jarosław Flis (2014) and Maciej Górecki (2015), but the research covered only parliamentary elections, and poviat was considered to be a basic territorial unit (Local Administrative Unit - Level 1).

The literature on the subject is not clear about the territorial scope of the FNV. Although in a large number of studies it was indicated that a candidate 
achieves better results in the unit of the place of residence, additional votes were not always shown in neighbouring units (although in such a case the possibility to infer is limited by the relativity of territorial units - e.g., the voting precinct surveyed in this text, which was considered to be adjacent to the precinct of the candidate's place of residence, would not have such a status if the basic unit of research were electoral districts, municipalities or poviats, together with other precincts it would be a part of the unit of the place of residence).

Disputes are caused by the operationalization of the FNV, which is most often defined by the place of residence, but which can be replaced by a place of birth (Meredith, 2013a, 2013b; Hessels, 2013) and a place of previous political activity. These selection may raise doubts for at least two reasons. Firstly, the place of residence usually changes over time. Secondly, relations with friends and neighbours may be connected with candidate's particular activity, related to his/her professional or social functions (e.g., doctor, teacher, leader of a nongovernmental organization) carried out away from his/her place of residence or birth.

Another doubt related to the operationalization of the FNV effect concerns its measurement - whether to quantify the distance between each voter and candidate and measure the relationship between the geographical distance and the probability of receiving votes, or rather whether to refer to administrative units (e.g., counties, municipalities, electoral districts, etc.), measuring support in the unit of residence and other units (in the latter case, it is also possible to distinguish intermediate categories - neighbouring units of the first and second order). The above doubt may be resolved by limitations in the availability of data. However, in the research conducted within urban areas taking a measure in the form of a geographical distance could be misleading. In electoral districts with multi-family houses, the distance of $1 \mathrm{~km}$ may be treated as being large, while in the outskirts, dominated by single-family houses and extensive green areas or water areas, it may be perceived as a neighbourhood (Evans et al., 2017, p. 61).

Previous research has unequivocally pointed to the strongly contextual nature of the FNV effect. The scale of its occurrence is significantly influenced by the electoral system (Childs \& Cowley, 2011) and the type of organization of political parties (Hazan, 1999). An open list system facilitates the occurrence of the FNV effect, as it reduces a potential conflict between party and personal motivations (Shugart, Valdini, \& Suominen, 2005).

The condition for the candidate's locality to play a role in voter's decisions is that the voter possesses information about the candidate's place of residence. If 
the voter is not cognizant of it, he or she cannot reward the candidate for being a local (Jankowski, 2016). This information is not included in ballot papers in Poland, as is the case, for example, in Germany.

Candidates on open lists have a strong motivation to build a personal reputation that will allow them to distinguish themselves from their rivals, particularly from the same list. On the other hand, extremely popular candidates may act as list pullers who gain so many votes for the list that it allows relatively unpopular candidates to obtain a mandate (Crisp et al., 2013). Place of residence as a voter's motivation may be defined as personal votes that are votes based on candidate's individual attributes. A method of building a politician's reputation may be to emphasize his or her locality, understood as his or her origin in a given place, but also as taking care of the interests of a local community. A party's rational strategy is then to build lists in such a way so as to ensure proper representation of as many territorial units as possible within the electoral district (Shugart et al., 2005).

The term PVEA (Personal Vote Earning Attribute) is used in the scientific literature. Candidates may have varying degrees of motivation to obtain personal votes. Although, of course, the intention of each candidate should be to obtain as many votes as possible, not everyone may be willing to evenly incur expenses in the form of time or financial resources. It can be assumed that candidates from low positions on the lists, who usually do not obtain a mandate, may have a weaker motivation to gain personal votes (Herron \& Lynch, 2019, pp. 11-12).

This article seeks to extend previous analyses of localism of candidates. To our knowledge, this is the first study of the FNV effect in Central and Eastern Europe employing the data of the candidate's exact place of residence. Previous surveys were based on the data gathered at the level of a municipality or a poviat. Secondly, the analysis does not rely on a straight-line distance between both places, as voters may consider distance in terms of territorial location rather than geographical distance and instead it uses dispersion of votes between electoral precincts, as in Poland votes in each precinct are counted and published separately. 


\section{LOCAL ELECTIONS IN SZCZECIN}

In the 2018 elections to the City Council of Szczecin, 155957 valid votes were cast, with a turnout of $52.08 \%$. 5 electoral districts were designated for the organization of the elections in the city (similarly as in the previous local government elections). In each of the districts, parties submitted separate lists of candidates.

Districts differed in terms of population size and number of voters, so the number of seats filled in a given district varied - from 5 to 7 , which can be defined as moderately small districts (Carey \& Hix, 2011). In the elections, a formal electoral threshold of $5 \%$ of all votes cast in the city area is in force. Seats are distributed within the districts according to the d'Hondt method, which, combined with the size of the districts, resulted in the occurrence of the so-called natural thresholds. Voters voted only for one candidate on one of the lists. Candidates on each of the lists were ranked in the order determined by the party. The lists were open and voters could modify the order, although, as the research demonstrates, it is not a frequent phenomenon due to the so-called ballot position effect (Marcinkiewicz, 2014).

Polish voters cannot rank all candidates on the list according to their preferences, nor can they vote for the list itself without indicating a person, but also changing the order does not require exceeding a certain threshold of the number of votes (as is the case with proportional elections with the so-called flexible lists).

The list of candidates could not contain fewer than 5 names of candidates; however, the number of candidates could not be higher than the number of councillors elected in a given electoral district, increased by two. It is worth noting that in such a system the number of losing candidates is usually many times greater than the number of winning candidates (who obtained a mandate).

In total, during the local government elections in Szczecin in 2018, there were 192 permanent voting precincts, and in 5 electoral districts there were respectively: $42,45,32,36$ and 36 voting precincts. Voting precincts are small units, which usually include between 1 and 2 thousand voters. As a result, they are typically homogeneous and include areas with uniform urban and social characteristics. The average number of persons entitled to vote in a precinct was 1554 , and an average number of persons voting in a precinct was 810 . The study did not include the so-called separate voting precincts, also sometimes referred to as special precincts, which are organized in places such as hospitals or jails, as residents from different areas of the city live in them. 
As a result of the election, 31 councillors to the Szczecin City Council were selected. In the election, 4 of 7 committees exceeded the five percent electoral threshold, but ultimately only 3 participated in the distribution of seats due to the existence of natural thresholds in the districts. The seats were given to the committees: Bezpartyjni, Law and Justice, Civic Coalition. Despite exceeding the formal threshold, Democratic Left Alliance did not obtain the seats. The above result, as far as the committees participating in the distribution of seats were concerned, was in line with the earlier opinion polls (Czapiewski, 2019).

\section{CANDIDATES' PLACE OF RESIDENCE}

Candidates were classified according to their place of residence. The provisions of the Polish electoral code make the right to stand for election conditional on having active electoral rights, which in this case means permanent residence in the city. However, it is not required that the candidate permanently resides in the voting district in which he or she is standing. Candidates who have been registered in the district in which they live are referred to as "local" for the purposes of this paper, and those who have their place of residence outside the district as "external".

As shown in Table 1, candidates often stand for election in a different district in Szczecin than their place of residence. As many as $41 \%$ of the candidates (100 out of 245) lived in the part of the city outside the district in which they were standing. Finally, as much as $45 \%$ (14 out of 31 ) of the elected City Council membership involved external candidates.

Table 1. Candidates by Place of Residence in Each District

\begin{tabular}{|l|c|c|c|c|c|c|}
\hline \multicolumn{1}{|c|}{ District } & $\mathbf{1}$ & $\mathbf{2}$ & $\mathbf{3}$ & $\mathbf{4}$ & $\mathbf{5}$ & Total \\
\hline Local & $\mathbf{4 1}$ & 26 & 17 & $\mathbf{2 8}$ & $\mathbf{3 3}$ & 145 \\
\hline External & 10 & 26 & $\mathbf{2 3}$ & 20 & 21 & 100 \\
\hline Total & 51 & 52 & 40 & 48 & 54 & 245 \\
\hline
\end{tabular}

There is a strong variation in the number of local and external candidates between districts. In one of the districts, there was a visible predominance of external candidates. Based on the chi-squared test, the dependence between the district and the place of residence in the candidate district was shown $(\mathrm{p}=0.003)$. 
It can also be noted that local candidates are more likely to be placed in positions $2-4$ on the list rather than in positions 1 or 5-9. It is worth noting that none of the candidates from positions 5-9 received a mandate in the analysed elections.

Table 2. Candidates by Place of Residence on Different Positions on the Lists

\begin{tabular}{|l|c|c|c|c|}
\hline \multicolumn{1}{|c|}{ Position } & $\mathbf{1}$ & $\mathbf{2 - 4}$ & $\mathbf{5 - 9}$ & Total \\
\hline Local & $\mathbf{1 6}$ & $\mathbf{6 2}$ & $\mathbf{6 7}$ & $\mathbf{1 4 5}$ \\
\hline External & 15 & 31 & 54 & 100 \\
\hline Total & 31 & 93 & 121 & 245 \\
\hline
\end{tabular}

In the age category, there is a clear advantage of local candidates in the oldest group (+60).

Table 3. Candidates by Place of Residence in Different Age Groups

\begin{tabular}{|l|c|c|c|c|c|c|}
\hline \multicolumn{1}{|c|}{ Age } & $\mathbf{1 9 - 3 0}$ & $\mathbf{3 1 - 3 9}$ & $\mathbf{4 0 - 4 9}$ & $\mathbf{5 0 - 5 9}$ & $\mathbf{6 0 +}$ & Total \\
\hline Local & 33 & 25 & 28 & 21 & 38 & 145 \\
\hline External & 28 & 17 & 24 & 19 & 12 & 100 \\
\hline Total & 61 & 42 & 52 & 40 & 50 & 245 \\
\hline
\end{tabular}

\section{METHODS AND RESULTS}

Spatial autocorrelation is multidirectional and can be reduced to the statement that the occurrence of a single phenomenon in a spatial unit causes an increase or decrease in the probability of occurrence of a given phenomenon in neighbouring units (Bivand, 1980). A popular method of spatial analysis of an attribute is the use of Moran's Global Statistics. This method makes it possible to determine whether a given attribute has concentrations in space or whether its distribution is random. The method was used to study electoral behaviour (Ames, 1995; Cutts \& Webber, 2010; Arzheimer et al., 2012).

The examined random variable was defined as a share of votes of a given candidate in a particular precinct in the total number of votes cast in a given precinct. In order to indicate neighbouring precincts, it was assumed that the vicinity must be immediate, i.e., it occurs when two areas share a common border. 
The average number of neighbouring precincts was 5 in each electoral district. The elements of the adjacency matrix take one of the two possible values - one when two areas are neighbours or zero otherwise. In order to obtain comparable results, the matrix has been standardized with rows and constructed for each of the circles separately, while the statistics was calculated for each of the candidates.

The basic hypothesis of the paper was that the place of residence is a factor that significantly affects the spatial distribution of votes.

Table 4. Moran I Values for Candidates by Place of Residence

\begin{tabular}{|l|c|c|c|c|}
\hline \multicolumn{1}{|c|}{$\begin{array}{c}\text { Place of } \\
\text { residence }\end{array}$} & Average I & $\begin{array}{c}\text { Standard deviation } \\
\text { I }\end{array}$ & $\begin{array}{c}\text { Average \% of expla- } \\
\text { nation of values }\end{array}$ & $\begin{array}{c}\text { Standard deviation } \\
\% \text { of explanation of } \\
\text { values }\end{array}$ \\
\hline Local & 0.189 & 0.233 & $8.98 \%$ & $14.35 \%$ \\
\hline External & 0.119 & 0.188 & $4.91 \%$ & $8.44 \%$ \\
\hline Total & 0.160 & 0.218 & $7.32 \%$ & $12.43 \%$ \\
\hline
\end{tabular}

A non-parametric Mann-Whitney U Test was conducted to determine the significance of differences between medians in the value of global Moran statistics between the group of local and external candidates. The U statistic value of 5955 for $\mathrm{p}=0.0176$ was obtained. Therefore, the null hypothesis of similarity of both groups of examined candidates should be rejected and it should be assumed that these groups differ significantly in the spatial distribution of votes. This means that both groups achieve significantly different results of Moran's global statistics, and therefore, the concentrations of votes are distributed in a different way.

The research was also conducted using the same method, but taking into account the so-called party coefficient, i.e., the differentiation of support for political parties in different areas, which could affect the individual performance of candidates regardless of their personal popularity. The party coefficient was developed on the basis of the results of the elections to the regional parliament (sejmik) in 2018, which are usually more party-based than the city council elections. It was shown that the party coefficient did not have a significant impact on the spatial distribution of votes of the examined group of candidates; therefore it was omitted in the further part of the study.

Tables 5 and 6 present the occurrence of significant spatial concentrations, divided into districts, separately for local and external candidates. It is noteworthy that, apart from a greater number of concentrations among local candidates, there is also a greater diversity between districts in this case. 
Table 5. Existence of Significant Concentrations of Spatial Support among Local Candidates by District

\begin{tabular}{|l|c|c|c|c|c|c|}
\hline \multicolumn{1}{|c|}{ District } & $\mathbf{1}$ & $\mathbf{2}$ & $\mathbf{3}$ & $\mathbf{4}$ & $\mathbf{5}$ & Total \\
\hline Significant & 14 & 6 & 0 & 3 & 7 & 30 \\
\hline Insignificant & 27 & 20 & 17 & 25 & 26 & 115 \\
\hline Total & 41 & 26 & 17 & 28 & 33 & 145 \\
\hline
\end{tabular}

Table 6. Existence of Significant Concentrations of Spatial Support among External Candidates by District

\begin{tabular}{|l|c|c|c|c|c|c|}
\hline \multicolumn{1}{|c|}{ District } & $\mathbf{1}$ & $\mathbf{2}$ & $\mathbf{3}$ & $\mathbf{4}$ & $\mathbf{5}$ & Total \\
\hline Significant & 2 & 4 & 2 & 1 & 0 & 9 \\
\hline Insignificant & 8 & 22 & 21 & 19 & 21 & 91 \\
\hline Total & 10 & 26 & 23 & 20 & 21 & 100 \\
\hline
\end{tabular}

The chi-square test checked the dependence of individual variables on the clustering of votes, separately for each of the samples. In the group of local candidates, the dependence of Moran's global statistics on the party $(p=0.002)$ and on being an incumbent $(\mathrm{p}<0.001)$ was demonstrated. For external candidates, the relationship between Moran's statistics and the district $(\mathrm{p}<0.001)$ and the party $(p=0.001)$ was shown. For local candidates, the relationship between the distribution of votes and population density was determined at the significance limit $\mathrm{p}=0.059$. The study of all candidates (local and external) revealed a significant correlation between Moran's global statistics and the district $(\mathrm{p}=0.004)$.

It is worth noting that no correlation was found between the number of significant concentrations of votes and the number of candidates living in a precinct, ballot position, gender or age of the candidate.

Table 7. Significance of Global Moran Statistics for All Candidates by District of Residence

\begin{tabular}{|l|c|c|c|c|c|c|}
\hline \multicolumn{1}{|c|}{ District } & $\mathbf{1}$ & $\mathbf{2}$ & $\mathbf{3}$ & $\mathbf{4}$ & $\mathbf{5}$ & Total \\
\hline Significant & 16 & 10 & 2 & 4 & 7 & 39 \\
\hline Insignificant & 35 & 42 & 38 & 44 & 47 & 206 \\
\hline Total & 51 & 52 & 40 & 48 & 54 & 245 \\
\hline
\end{tabular}


Another method used in the study involved analysing the spatial distribution of votes is the local Moran statistic, which is a type of Local Indicators of Spatial Association (LISA). It describes the similarity of a spatial unit to adjacent units. There are five possible interpretations of the results of this measure for a single unit: $\mathrm{HH}$ (hot spot) - a unit of high value of a variable surrounded by neighbours of similar values, LL (cold spot) - a unit of low value of a variable surrounded by neighbours of similar values, HL - a unit of high values surrounded by neighbours of low values of the tested variable, $\mathrm{LH}-\mathrm{a}$ unit of low values surrounded by neighbours of high values, and the last group encompasses units without statistically significant spatial autocorrelation.

Among local candidates, 30 were characterized by the creation of clusters in space, of which the dominating cluster was the HH cluster, in the remaining cases (2) it was the LL cluster. Among external candidates, 9 out of 100 were characterized by the presence of clusters of votes and in most cases (6) these were high value clusters.

Among the local candidates, in whose cases clusters of votes were observed, the dominant clusters (in which Moran's local statistics reached their highest values) could be located in the precinct of the candidate's place of residence, in a neighbouring precinct or another one, not adjacent to the precinct of the place of residence. In 14 cases the dominating cluster was the precinct of residence and in 11 cases it was a neighbouring precinct. In both situations, all dominating clusters were of $\mathrm{HH}$ type. In 5 cases the dominant cluster turned out to be located in a different precinct, of which 1 cluster was an LL type cluster.

Among 14 out of 30 local candidates with clusters of votes, the percentage of explanation of the value exceeded $30 \%$. Only two external candidates exceeded the $30 \%$ threshold, and their concentration of support may be interpreted in accordance with the assumptions underlying the description of the FNV effect. One of these candidates had previously been selected as a neighbourhood councillor in the district in which he stood as a candidate (in order to be a candidate for the neighbourhood council, one had to live in a neighbourhood, so the place of residence outside the district had to be short-lived). The second candidate lived outside the district, but in its immediate vicinity, and the concentration of support occurred within border precincts, in the geographical proximity of the candidate's place of residence. In all cases of the high level of explanatory value (30\%), the cluster was of $\mathrm{HH}$ type. In 11 out of these 14 cases it occurred in the precinct of residence or in a neighbouring precinct. 
Table 8. Location of the Dominating Cluster for Local Candidates with Significant Spatial Concentrations of Votes by Cluster Type

\begin{tabular}{|l|c|c|c|}
\hline \multicolumn{1}{|c|}{ Type of cluster } & HH & LL & Total \\
\hline Residence & 14 & 0 & 14 \\
\hline Neighbouring & 11 & 0 & 11 \\
\hline Other & 4 & 1 & 5 \\
\hline Total & 29 & 1 & 30 \\
\hline
\end{tabular}

If a candidate had significant spatial concentrations of votes that covered many precincts, including the precinct of residence or a neighbouring precinct, this phenomenon can be described as the FNV in a broader sense. This may exclude cases in which the voting effect has a smaller territorial scope, which refers to real family, friendship or neighbourly relations, and the candidate's locality is unknown or known on a very small scale in precincts other than the precinct of residence. Therefore, the results of voting in the precinct of residence of local candidates were also examined by calculation of the Moran's local statistics taking into account their significance. As many as 65 out of 145 (44.83\%) local candidates had a significant concentration of votes in the precinct of residence. In all cases it was either $\mathrm{HH}$ or HL type. There was no significant vote concentration of LL or LH type in the precinct of residence.

Table 9. Significance of Local Moran Statistics for Local Candidates by Cluster Type

\begin{tabular}{|l|c|c|c|c|c|}
\hline \multicolumn{1}{|c|}{ Cluster type } & HH & HL & LH & LL & Total \\
\hline Significant & 58 & 7 & 0 & 0 & 65 \\
\hline Insignificant & 49 & 20 & 6 & 5 & 80 \\
\hline Total & 107 & 27 & 6 & 5 & 145 \\
\hline
\end{tabular}

Table 10. Significance of Local Moran Statistics for External Candidates by Cluster Type

\begin{tabular}{|l|c|c|c|c|c|c|}
\hline \multicolumn{1}{|c|}{ District } & $\mathbf{1}$ & $\mathbf{2}$ & $\mathbf{3}$ & $\mathbf{4}$ & $\mathbf{5}$ & Total \\
\hline Significant & 23 & 13 & 5 & 12 & 12 & 65 \\
\hline Insignificant & 18 & 13 & 12 & 16 & 21 & 80 \\
\hline Total & 41 & 26 & 17 & 28 & 33 & 145 \\
\hline
\end{tabular}


Among the 30 local candidates indicated above, who were observed to have clusters of votes according to Moran's global statistics, in 24 cases there was a significant voting cluster in the $\mathrm{HL}$ or $\mathrm{HH}$ precinct of residence.

What is particularly interesting, there was no significant correlation between the presence of a significant $\mathrm{HH}$ or $\mathrm{HH}$ cluster in the precinct of residence and the party, district, number of candidates living in the region, ballot position, gender or age of the candidate.

\section{ANALYSIS AND DISCUSSION}

The conducted research indicates that the intensity of the FNV effect differs between candidates. This local bonus, which in fact is the FNV effect, is an attribute of selected candidates.

The study of the characteristics of external candidates who showed clusters of support points to an interesting catalogue of circumstances that may result in the creation of local bonuses other than the place of residence. Two cases connected with changing the place of residence and living in the immediate vicinity of the district were described earlier, while the next cases concerned most often the function of the headmaster or deputy headmaster of a school in a district or conducting charity activities in a parish located in a district. However, most of the cases of clusters of support for external candidates can be somehow connected with the place of residence or other type of activity conducted before the election campaign.

It is worth pointing out that candidates with a strong local concentration of support most often stand from the lists that exceeded the electoral threshold in districts 1,2, or 5 (respectively $97 \%$ and $85 \%$ ). Local bastions of support for candidates from lists participating in the division of seats may be explained by referring to the notion of motivation to win personal votes. Candidates from lists with low support and candidates on a lower ballot positions describe their chances of winning a mandate as low.

One can also try to explain this phenomenon in a different way, by focusing on the party strategies of the selectors. The parties building the lists may be the ones that are looking for candidates who could make a contribution in the form of personal votes. Candidates from low positions are not considered as important for the party's success. However, the highest rank on the list is given first and foremost to the candidates holding a high position in the party, which does not 
always have to be associated with a personal reputation among voters and the ability to generate personal votes.

Differences in electoral characteristics of districts are visible. The analysis of the localness of candidates divided into districts leads to interesting conclusions. There is a clear disproportion in the relation between the number of local and external candidates in different districts. District 1 shows a clear advantage of local candidates. This district includes the part of the city called "Prawobrzeże", which is distant from the City Centre, separated by a river and a wide strip of industrial and port areas. "Prawobrzeże" is the part of the city with the lowest population density and which features, among others, a number of small housing estates with extensive presence of single-family housing.

District No. 3 is distinguished by the predominance of external candidates. District 3 is located mainly within the boundaries of the City Centre. A large part of District 2 also lies within its borders. Research into electoral behaviour of Szczecin's inhabitants (Czapiewski, 2016) indicates that these are the areas which, in comparison with the rest of the city, are characterized by a consistently lower turnout than in other areas of the city. At the same time, there are changes in the demographic structure - with an increasing share of older people, and the associated depopulation, which is related to the suburbanisation process (residents moving from the City Centre to the outskirts or to neighbouring counties). In the case of candidates, there is a phenomenon that can be called reverse suburbanisation. It may be related to two processes. Firstly, it may be the result of the suburbanisation process - the politicians initially lived in the City Centre and, while running for office in that district, changed their place of residence while maintaining their original area of electoral activity. It may also result from the fact that the district has a low level of electoral participation, which includes not only the exercise of active but also passive voting rights. In view of such a gap, committees must reach out to residents of other districts to fill out the lists.

If politicians who are described as external also often win seats, this can raise doubts as to the representation of residents in particular areas. This is particularly true in the inner-city areas, where voters often do not even have the opportunity to vote for a local candidate, all the more so in accordance with their party preferences.

It can be seen that a candidate's locality is a more important attribute influencing voting results in certain city districts, while in others it is of limited importance. These characteristics of districts are consistent, manifested both in the level of presence of local candidates on the lists and in the results of voting 
for local candidates. The smallest degree of territorial differentiation was visible in the case of the so-called narrow FNV effect.

It is worth noting the problem of identification with a district/neighbourhood understood as "a city within a city", a sense of identity related to a specific space (Kallus \& Law-Yone, 2000). People identify themselves with territorial units with clear boundaries (Lewicka, 2010) - usually the sense of identification with their own house/apartment or the whole city is much stronger. Therefore, the FNV effect does not have to be stronger in smaller-scale elections held in smaller districts, if these divisions are artificial and there are no local ties, there is only the awareness of the city, although only with some reservations. An exception to this rule involves housing estates located in the outskirts, distant from the city Centre, with single-family houses, built on the basis of villages absorbed by the city and sparsely populated.

Relationships are visible in a wide FNV view, but not in a narrow view. In combination with the indication that a clearly higher number of candidates shows a narrow FNV effect, this may lead to the conclusion that this is a natural effect indeed connected with the fact of a family relationship or close neighbourhood. Only an active politician with experience in performing his or her function, strengthened by a popular party, can build a wider local effect, not connected with the family and neighbourhood network. The question of interpretation and further research is to indicate the mechanism and causal links in this phenomenon. First of all, it may be connected with the issue of information - in the case of candidates of large parties or incumbents, voters may be more likely to know that such a person is a candidate in elections and resides within a short distance (a ballot paper does not contain the latter information, and in the case of a multitude of candidates, one may doubt whether the voter will become acquainted with all of them). It may also result from the fact that the candidate built a kind of "a district within a district" in the vicinity of the place of residence - it is there that he or she concentrated the election campaign, referred to the local identity of the neighbourhood in the election materials, and formulated and implemented earlier postulates regarding this area (e.g., renovations of streets in the area, creation of new places for cultural or physical activity). Candidates running from high positions on the list of popular parties are also more motivated to expand their area of activity, knowing that the expenses incurred may pay off in the form of obtaining mandates and any consequential benefits associated with it.

Although, as indicated, there is no correlation between the number of significant concentrations of votes and the number of candidates from a precinct, the 
analysis of individual cases of candidates and campaigns demonstrates that it is important to properly select the size of "a district within a district" - it should not be too small, but at the same time it ought to have clear boundaries and a related local identity. A larger number of candidates effective in building the image of a neighbourhood representative and defender of local interests may result in a reduction in the size of a local voting bonus and a smaller chance of obtaining a mandate, especially if they are ranked lower on the list.

Some doubt may be expressed as to whether the notion of friends and neighbours voting is appropriate to describe this FNV effect in a broader sense. Existing practice refers to the concept of voting on a scale of even regions, where a voter living at a distance of, e.g., $100 \mathrm{~km}$ is treated as a neighbour. It seems more appropriate in this context to talk about the effect of the local origin of the candidate. Especially since, as the presented research may suggest, different causal mechanisms may underlie in the two approaches behind the increased number of votes.

It can be assumed that such a high number of external candidates is due to two reasons. First, it seems more important, especially for the highest ranked candidates, to maintain a high rank on the list than to start from one's own district if both expectations cannot be met. Secondly, this type of election generates a huge number of losers, many more than winners. Therefore, parties may have to deal with the problem of filling lower positions on the lists, which have little chance of gaining a mandate.

The fact that a party has a large number of local candidates does not necessarily mean that these candidates will receive higher local bonuses. The committee that had the highest percentage of local candidates had only one candidate with a significant concentration of votes.

It is worth noting that there are mainly significant concentrations of $\mathrm{HH}$, rarely $\mathrm{HL}$, while the LH and LL ones are practically non-existent. Therefore, there is no personal unpopularity of a candidate in this type of elections. It also confirms that other factors, such as differences in support for the party, are not a significant element influencing the spatial distribution of votes for candidates in this case, because if it were otherwise, LL or LH clusters would be more frequent.

It is worth noting the composition of the City Council, while taking into account the position on the list. 25 out of 31 seats were filled in accordance with the ballot position. Among 5 out of 6 candidates who won the mandate contrary to their position, there were significant territorial concentrations of support (with the exception of the candidate from the inner-city District 3), usually with a high percentage of explanation of values $(63 \%, 50 \%, 40 \%, 27 \%, 16 \%)$. 
This may lead to the hypothesis that building a local support is the most effective method of correcting the effect of ballot position and obtaining a mandate. Such a hypothesis should be examined in relation to extended empirical material - to other geographical areas, but especially to other types of elections. The cases of voters correcting the order of the list should deserve special research interest.

\section{CONCLUSIONS}

Studies of the case of local elections in Poland on the example of one large city lead to the conclusion that election lists often include candidates residing outside the electoral district. This phenomenon is territorially diversified and to a greater extent concerns areas of inner-city character.

The spatial distribution of votes of candidates who have their place of residence in the area from which they stand for election is significantly different from the distribution of votes among non-resident candidates. This phenomenon is visible in local elections in the proportional system with open lists. The analysis of the spatial distribution of votes indicates that there is a phenomenon of additional personal votes, but in such an election system there is no analogous phenomenon of local unpopularity of a candidate, which would be manifested by spatial concentrations of weaker results.

There are two ranges of the FNV voting effect. In a narrower perspective, it is limited mainly to the precinct of residence. In a broader perspective, it also includes neighbouring precincts, also those of second degree. The effect of voting in the first approach is more frequent. In the case of the voting effect in a broader perspective, the relationships revealed may lead to a hypothesis that there is another causal mechanism, incompatible with the literal meaning of the name of the term 'FNV effect'. Apart from a stronger territorial differentiation of the FNV effect in a broad perspective, the dependence of the effect on party affiliation was also pointed out. However, in such an election system a large number of candidates do not show any statistically significant concentration of votes in their precinct of residence and it is difficult to talk about the effect of FNV in their case. A party factor may deserve to be developed in further research.

A new research perspective may also include the occurrence of a spatial concentration of votes as an element explaining the size of a candidate's electoral support, which is based primarily on the size of support for the party and the ballot position. 


\section{REFERENCES:}

Ames, B. (1995). Electoral Strategy under Open-List Proportional Representation. American Journal of Political Science, 39(2), 406-433. DOI: 10.2307/2111619.

André, A., \& Depauw, S. (2018). Looking beyond the District: The Representation of Geographical Sub-Constituencies across Europe. International Political Science Review, 39(2), 256-272. DOI: 10.1177/0192512116671527.

Arter, D. (2011). Taking the Gilt off the Conservatives' Gingerbread: The April 2011 Finnish General Election. West European Politics, 34(6), 1284-1295. DOI: 10.1080/01402382.2011.616666.

Arzheimer, K., \& Evans, J. (2012). Geolocation and Voting: Candidate-Voter Distance Effects on Party Choice in the 2010 UK General Election in England. Political Geography, 31(5), 301-310. DOI: 10.1016/j.polgeo.2012.04.006.

Arzheimer, K., \& Evans, J. (2014). Candidate Geolocation and Voter Choice in the 2013 English County Council Elections. Research \& Politics, 1(2). DOI: $10.1177 / 2053168014538769$.

Bengtsson, A., \& Wass, H. (2011). The Representative Roles of MPs: A Citizen Perspective. Scandinavian Political Studies, 34(2), 143-167. DOI: 10.1111/j.14679477.2011.00267.x.

Bivand, R. (1980). Autokorelacja przestrzenna a metody analizy statystycznej w geografii. In: Z. Chojnicki (Ed.). Analiza regresji w geografii (pp. 23-38). WarszawaPoznań: PWN.

Black, A., \& Black, M. (1973). The Wallace Vote in Alabama: A Multiple Regression Analysis. Journal of Politics, 35(3), 730-736. DOI: 10.2307/2129154.

Blais, A., Gidengil, E., Dobrzynska, A., Nevitte, N., \& Nadeau, R. (2003). Does the Local Candidate Matter? Candidate Effects in the Canadian Election of 2000. Canadian Journal of Political Science, 36(3), 657-664. DOI: 10.1017/S0008423903778810.

Campbell, R., \& Cowley, P. (2014). What Voters Want: Reactions to Candidate Characteristics in a Survey Experiment. Political Studies, 62(4), 745-765. DOI: 10.1111/1467-9248.12048.

Carey, J.M., \& Hix, S. (2011). The Electoral Sweet Spot: Low凹Magnitude Proportional Electoral Systems. American Journal of Political Science, 55(2), 383-397. DOI: 10.1111/j.1540-5907.2010.00495.x.

Carey, J.M., \& Shugart, M.S. (1995). Incentives to Cultivate a Personal Vote: A Rank Ordering of Electoral Formulas. Electoral Studies, 14(4), 417-439. DOI: 10.1016/0261-3794(94)00035-2.

Childs, S., \& Cowley, P. (2011). The Politics of Local Presence: Is There a Case for Descriptive Representation? Political Studies, 59(1), 1-19. DOI: 10.1111/j.14679248.2010.00846.x.

Collignon-Delmar, S., \& Sajuria, J. (2018, January 23). Who Cares about Local Candidates? Finding Voters That Use Candidate Localness as a Cue for Their Vote Choices. Retrieved from: https://osf.io/j5rpy/download. 
Crisp, B.F., Olivella, S., Malecki, M., \& Sher, M. (2013). Vote-Earning Strategies in Flexible List Systems: Seats at the Price of Unity. Electoral Studies, 32(4), 658-669. DOI: 10.1016/j.electstud.2013.02.007.

Cutts, D., \& Webber, D.J. (2010). Voting Patterns, Party Spending and Relative Location in England and Wales. Regional Studies, 44(6), 735-760. DOI: 10.1080/00343400903107744.

Czapiewski, T. (2016). Mapa wyborcza Szczecina. Przestrzenne zróżnicowanie zachowań wyborczych szczecinian w latach 2006-2015. Acta Politica Polonica, 36(2), 21-34. DOI: 10.18276/ap.2016.36-02.

Czapiewski, T. (2019). Wybory samorządowe w Szczecinie w 2018 roku. Analiza statystyczna i przestrzenna. In: U. Chęcińska, \& T. Czapiewski (Eds.). Kronika Szczecina za rok 2018. Miasto w stulecie odzyskania przez Polskę niepodległości (pp. 171-190). Szczecin: Wydawnictwo Naukowe US.

Eder, N., Jenny, M., \& Müller, W.C. (2015). Winning Over Voters or Fighting Party Comrades? Personalized Constituency Campaigning in Austria. Electoral Studies, 39, 316-328. DOI: 10.1016/j.electstud.2014.04.008.

Evans, J., Arzheimer, K., Campbell, R., \& Cowley, P. (2017). Candidate Localness and Voter Choice in the 2015 General Election in England. Political Geography, 59, 61-71. DOI: 10.1016/j.polgeo.2017.02.009.

Fiva, J.H., \& Smith, D.M. (2017). Local Candidates and Voter Mobilization: Evidence from Historical Two-Round Elections in Norway. Electoral Studies, 45, 130-140. DOI: 10.1016/j.electstud.2016.11.021.

Flis, J. (2014). Złudzenia wyboru. Społeczne wyobrażenia i instytucjonalne ramy w wyborach do sejmu i senatu. Kraków: Wydawnictwo Uniwersytetu Jagiellońskiego.

Forrest, J., \& Johnston, R.J. (1973). Spatial Aspects of Voting in the Dunedin City Council Elections of 1971. New Zealand Geographer, 29(2), 166-181. DOI: 10.1111/j.17457939.1973.tb00711.x.

Górecki, M. (2015). „Głosowanie przyjacielsko-sąsiedzkie”: Przyczynek do badań w kontekście polskim. Studia Socjologiczno-Polityczne. Seria Nowa, 3(1), 63-73.

Hazan, R.Y. (1999). Constituency Interests without Constituencies: The Geographical Impact of Candidate Selection on Party Organization and Legislative Behavior in the $14^{\text {th }}$ Israeli Knesset, 1996-99. Political Geography, 18(7), 791-811. DOI: 10.1016/ S0962-6298(99)00028-1.

Hazan, R.Y., \& Rahat, G. (2010). Democracy within Parties: Candidate Selection Methods and Their Political Consequences. Oxford: Oxford University Press.

Herron, E.S., \& Lynch, M.S. (2019). 'Friends and Neighbors' Voting under Mixed-Member Majoritarian Electoral Systems: Evidence from Lithuania. Representation, 55(1), 81-99. DOI: 10.1080/00344893.2019.1581078.

Hessels, M. (2013, December). Nationwide Localism: Voter-Candidate Proximity Effects in Two Types of Dutch Elections. Master's Thesis. Amsterdam: University of Amsterdam. 
Jankowski, M. (2016). Voting for Locals: Voters' Information Processing Strategies in Open-List PR Systems. Electoral Studies, 43, 72-84. DOI: 10.1016/j.electstud.2016.06.005.

Johnston, R.J. (1974). Local Effects in Voting at a Local Election. Annals of the Association of American Geographers, 64(3), 418-429. DOI: 10.1111/j.1467-8306.1974. tb00990.x.

Johnston, R., Wickham-Jones, M., Pattie, C., Cutts, D., \& Pemberton, H. (2016). Friends and Neighbours Voting Revisited: The Geography of Support for Candidates to Lead the UK's Labour Party. Political Geography, 55, 1-9. DOI: 10.1016/j. polgeo.2016.02.003.

Kallus, R., \& Law-Yone, H. (2000). What Is a Neighbourhood? The Structure and Function of an Idea. Environment and Planning B: Planning and Design, 27(6), 815-826. DOI: $10.1068 / \mathrm{b} 2636$.

Kavanagh, A., Mills, G., \& Sinnott, R. (2004). The Geography of Irish Voter Turnout: A Case Study of the 2002 General Election. Irish Geography, 37(2), 177-186. DOI: $10.1080 / 00750770409555841$.

Key, V.O. (1949). Southern Politics in State and Nation. New York: Knopf.

Lewicka, M. (2010). What Makes Neighborhood Different from Home and City? Effects of Place Scale on Place Attachment. Journal of Environmental Psychology, 30(1), 35-51. DOI: 10.1016/j.jenvp.2009.05.004.

Lewis-Beck, M.S., \& Rice, T.W. (1983). Localism in Presidential Elections: The Home State Advantage. American Journal of Political Science, 27(3), 548-556.

Malcová, K. (2012). The Local Aspect of Electoral Support for Candidates to the Senate of the Czech Republic. Sociologický ćasopis - Czech Sociological Review, 48(2), 283-313. DOI: 10.13060/00380288.2012.48.2.04.

Marcinkiewicz, K. (2014). Electoral Contexts That Assist Voter Coordination: Ballot Position Effects in Poland. Electoral Studies, 33, 322-334. DOI: 10.1016/j.electstud.2013.07.018.

Meredith, M. (2013a). Exploiting Friends-and-Neighbors to Estimate Coattail Effects. American Political Science Review, 107(4), 742-765. DOI: 10.1017/ S0003055413000439.

Meredith, M. (2013b, October 7). Heterogeneous Friends-and-Neighbors Voting. Working Paper. University of Pennsylvania. Retrieved from: https://www.sas.upenn. edu/ marcmere/workingpapers/HeterogeneousLocalism.pdf.

Put, G.J. (2015). All Politics Is Local: The Geographical Dimension of Candidate Selection. The Case of Belgium (1987-2010). PhD Thesis. Leuven: KU Leuven.

Rice, T.W., \& Macht, A.A. (1987a). Friends and Neighbors Voting in Statewide General Elections. American Journal of Political Science, 31(2), 448-452. DOI: $10.2307 / 2111084$.

Rice, T.W., \& Macht, A.A. (1987b). The Hometown Advantage: Mobilization or Conversion? Political Behavior, 9(3), 257-262. DOI: 10.1007/BF00988615. 
Roy, J., \& Alcantara, Ch. (2015). The Candidate Effect: Does the Local Candidate Matter? Journal of Elections, Public Opinion \& Parties, 25(2), 195-214. DOI: 10.1080/17457289.2014.925461.

Shugart, M.S., Valdini, M.E., \& Suominen, K. (2005). Looking for Locals: Voter Information Demands and Personal Vote冈Earning Attributes of Legislators under Proportional Representation. American Journal of Political Science, 49(2), 437-449. DOI: $10.2307 / 3647687$.

Simiyu, R. (2010). Politics of Residency, Friends and Neighbors Effect, and Voting Patterns in Kwanza Constituency, Kenya, 1988-2000. African Geographical Review, 29(1), 37-61. DOI: 10.1080/19376812.2010.9756225.

Tavits, M. (2010). Effect of Local Ties on Electoral Success and Parliamentary Behaviour: The Case of Estonia. Party Politics, 16(2), 215-235. DOI: $/ 10.1177 / 1354068809341053$.

Vandeleene, A. (2017). Friends and Neighbours Politics in Belgian Candidate Selection Processes. Does Place Matter? Conference Paper. Oslo: ECPR General Conference. 